\title{
Heritage and Festivals in Europe
}

Performing Identities

\section{Edited by Ullrich Kockel, Cristina Clopot, Baiba Tjarve and Máiréad Nic Craith}

First published 2020

ISBN: 978-0-367-18676-0 (hbk)

ISBN: 978-0-429-20296-4 (ebk)

\section{Heritages, identities and Europe}

Exploring cultural forms and expressions

Ullrich Kockel, Máiréad Nic Craith, Cristina Clopot and Baiba Tjarve

(CC BY-NC-ND 4.0)

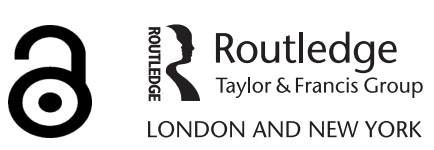




\title{
1 Heritages, identities and Europe

\author{
Exploring cultural forms and expressions
}

\author{
Ullrich Kockel, Máiréad Nic Craith, \\ Cristina Clopot and Baiba Tjarve
}

Traditional arts practices and festivals have attracted increasing and diverse attention in the European context since policymakers discovered 'culture' as a resource in the 1980s (see, e.g., Kilday 1998). Their impact on their respective communities of practice, modes of production and exchange value in contemporary European society is under the spotlight from various angles within the newly emerged field of 'festival studies', which is deeply connected to policy issues (Frost 2016). However, much of this interest is instrumentally concerned with revenue potential, leaving key concepts, such as heritage, identity and indeed Europe, defined in rather vague and often contradictory terms (Kockel, Nic Craith and Frykman 2012; Logan, Kockel and Nic Craith 2015; Kølvraa 2016; Lähdesmäki 2016; Whitehead and Bozoğlu 2017). Moreover, the number and range of events labelled as 'festival' is growing (Frost 2016: 569), requiring a broader perspective on performances of heritage and identity.

The present volume arose from a research programme that set out to examine, from a critical heritage perspective, how the European project (Lähdesmäki 2011) has been manifesting itself in terms of policy, values, heritage, and performance of traditional arts. Empirically and theoretically concerned with both popular and institutionalised practices of heritage making, the programme has addressed especially the gap between discourses of heritage at official including European - level and actual cultural practice, often informal or unofficial, at the local and regional level. Researchers have explored in particular heritage festivals - broadly defined - as sites for the reframing of collective memory and the reinterpretation of the notion of a common European heritage. With reference to the Olympic Games, MacAloon (1984: 1) claimed that festivals are 'occasions where as a culture or society we can reflect upon and define ourselves, dramatise our collective myths and history, present ourselves with alternatives and eventually changing ourselves in some ways while remaining the same in others'. And, as Fabiani (2005: 64) noted, 'ff]estivals are always crowded with argumentative people, who disagree about many things but who hold at least one belief in common: that the festival is the archetype of public space, where physical closeness and a right to speak define the primary conditions of collective life'. In that sense, heritage festivals are opportunities for citizens to negotiate, articulate and transform their European identity (Fligstein 


\section{Ullrich Kockel et al.}

et al. 2012; Kaina and Karolewski 2009) at local level. Given tourism's major and growing economic role, and its sociocultural as well as environmental impacts, several contributors to this volume consider heritage festivals as tourism events.

Cultural traditions, being part of cultural heritages, are significant factors that shape local, regional, national and European identities. From the late 1950s, Bausinger (1961) and others have turned the ethnological searchlight from the disappearing world of the European peasantry as the guardians of tradition and heritage towards contemporary and emerging cultural forms and expressions. Among other factors, demographic transformation through international migration and ageing established populations, the commercialisation and commodification of traditional lifestyle elements in the course of globalisation, and IT developments, including social media, have affected the continuity of traditions. The 'heritage boom' from the 1980s onwards has raised awareness of the importance of cultural resources in a broad sense, although much of this has shared the intuition of a 'salvage ethnology' concerned solely with the preservation of heritage items (Kockel 2002). Meanwhile in many European countries, cultural communities and cultural policymakers look for policy strategies and measures for how to develop cultural traditions, safeguard intangible cultural heritages $(\mathrm{ICH})$ and ensure their sustainability for future generations (Nic Craith, Kockel and Lloyd 2019). Beyond this, there has been growing interest in the development of 'heritage futures' (Nic Craith and Kockel 2002; see also Holtorf and Högberg 2013), that is, new forms and expressions of tradition and heritage. The capacity of what the ethnologist Hamish Henderson called the 'carrying stream' (see Bort 2012) of tradition, to sustain and regenerate cultural heritages, arguably rests as much in its innovative power as it does in its potential for conservation (Kockel 2008). As ecological contexts (Frost 2016) for the making, unmaking and remaking of group identities, 'festivals can be seen as political formations open to multiple uses both from above and below' (Leal 2016: 594). The contributors to this book examine the different factors influencing the sustainable development of tradition as part of $\mathrm{ICH}$ at different levels and trace underlying common structures. Focussing on case studies of selected regions and cultural groups across Europe, they explore increasingly interconnected heritages and provide examples of heritage-making that simultaneously look backwards and forwards, at the same time addressing the complexities of heritage in contemporary Europe from different theoretical positions.

Most of the research presented here focusses on festivals and performances of different types and reflects the interdisciplinarity that has become somewhat of a hallmark of heritage research (Waterton and Watson 2015). The term 'performance' has acquired many possible meanings and applications in the arts, humanities and social sciences. A performance may be a specific event that involves presentation of rehearsed, often artistic, actions, such as a play or an opera, or it may refer to any kind of event involving a performer and a spectator, from a tennis match to a shamanic ritual. But performance is also a complex and contested concept that helps us to understand social 
and cultural processes. McKerrell and Pfeiffer (this volume), engaging with scholarship on performance from different disciplines, explore various scholarly approaches to performance and the cultural work performance does, from theatre and performance studies to ethnomusicology. They focus on performance as an embodied act of communication between performers and audiences that facilitates an affective exchange with effects that reverberate beyond the moment. Their analysis illustrates how performances as a means of meaningmaking, in which meaning is co-created between performers and audiences, provide opportunities to explore questions about the social and cultural role of imaginative interpretations of ICH. In a sense, all chapters in this collection emphasise the performative aspects of festivals and of the issues and tensions arising from communities' efforts to transmit and transform practices, values and traditions through them. Performance and transformation of heritage are treated in the present collection as cultural forms and expressions of identity in general, and a European identity of sorts in particular. The key terms and underlying concepts directing and demarcating the research - heritage, identity, Europe - thus offer a useful way of framing the collection.

\subsection{Heritage}

Leal (2016: 594f.) analyses 'heritage making as group making'. Few discussions of heritage festivals can proceed without delimiting the scope of the slippery concept of heritage (see Logan, Kockel and Nic Craith 2015) and its limitations in current use, especially the increasingly contested separation between tangible and intangible heritage (Nic Craith and Kockel 2015). Moreover, institutionalised heritage-making practices (Harvey 2001) and grassroots efforts (Nic Craith 2012; McFadyen and Nic Craith, this volume) that might at times stand against such top-down approaches (Hafstein 2012; Taylor 2016), need to be problematised because " $\mathrm{t}$ ]he latter have become more salient under the current regime of "heritagisation" promoted by UNESCO's category of Immaterial Cultural Heritage' (Leal 2016: 594).

With its various conventions, the United Nations Educational, Scientific and Cultural Organisation (UNESCO 1954; 1970; 1972; 2001; 2003) has drawn attention to different dimensions of heritage. While much academic, policy and professional interest in heritage concentrates on material culture, and this therefore inevitably features throughout this book, our focus is on ICH. UNESCO's 2003 Convention for the Safeguarding of the Intangible Cultural Heritage suggests that $\mathrm{ICH}$ is particularly evident in the following domains:

- oral traditions and expressions, including language as a vehicle of the intangible cultural heritage;

- $\quad$ performing arts;

- $\quad$ social practices, rituals and festive events;

- $\quad$ knowledge and practices concerning nature and the universe;

- traditional craftsmanship. 
While all of the above feature in case studies throughout the book, the notion of 'festivals' provides a focal point that brings together different aspects of ICH, with an emphasis on performance and on the issue of the European-ness of these heritages. Who owns the heritages that are celebrated at these festivals? How does one strike a balance between various local and translocal domains of ownership? How are the interests of tradition-bearers protected at the European level? Such tensions reflect the debate generated by the European Union's motto of 'unity in diversity', a term that can be interpreted in multiple ways. For example, a study of the European discourse of German expellee associations (Kockel, this volume) indicates the co-existence of conflicting versions - parallel versus integral - within the same historical heritage context. On the one hand, this might be regarded as an affirmation of diverse expressions of ICH, which ultimately remain at the local level. On the other hand, where policy supports one or other of these versions, it might be regarded as appropriation of expressions of identity by the centre for its own ends; this may wrest ownership of ICH from the local level just as much as commodification can (Kockel 2007).

A key case study in the research programme from which this book arose is the Song and Dance Celebration tradition in the Baltic States, designated by UNESCO as a masterpiece of the oral and intangible heritage of humanity in 2003. The research covered several aspects of this festival: cultural, economic, social and governance. Muktupāvela and Laķe (this volume) develop a quantitative analysis of the potential of festivals for national branding. Two forms of how international recognition may be developed are outlined: special strategies created either by experts more or less spontaneously and national identity brands stemming from traditional cultural symbols that are important for people on the ground. At the beginning of the twenty-first century, the Baltic States have attempted via purposeful, state-financed policies to 'brand' their nations. During this process, the use of informal symbols, such as the 'singing nations', so characteristic for the Baltic region, was deliberately avoided. Nevertheless, this symbol, which is rooted in the Song and Dance Celebration, has remained an important and influential agent from cultural, social, ideological and economic points of view.

Driven in part by an increased awareness of tourism benefits, the appeal of heritage festivals has increased exponentially across Europe (Testa 2017). It is now widely accepted that festivals represent occasions for identity-building (Frost 2016) and that they can foster belonging (Kuutma 1998). Reflecting on identity as a binary process, with self-identification involving the drawing of boundaries in relation to 'others' (Barth 1969), Clopot and McCullagh (this volume) examine identity processes of performers and participants at heritage festivals. Drawing on ethnographic fieldwork in two distinct locations, they analyse these processes by taking a comparative view of two festivals celebrating migrant heritage. A Scottish fire festival related to Viking heritage, $U p$-Helly-Aa in Shetland, is contrasted with the multicultural Romanian festival Proetnica. Whereas in the former, 'othering' appears set across gender divisions, the latter 
illustrates the difficulties of negotiating majority/minority relations even in the context of a festival designed to promote pluralism and diversity.

Heritage is often associated with nostalgia, an issue that in many ways [has] been a persistent and even notorious issue within the field of heritage studies from its very inception' (Campbell, Smith and Wetherell 2017: 609). Regarded as inaccurate and sentimental, it has been shunned as a research topic and considered inappropriate for framing heritage interpretation. Drawing on data collected at the Cappadox festival in Turkey, research by Taheri, Gannon and Olya (this volume) offers a different perspective on heritage and nostalgia. Grounding their study in a perspective of interactive sociality, they reflect on the instrumentalisation of nostalgia (Clopot 2017) for enhancing belonging. While it is acknowledged that festivals and cultural events are powerful, interactive venues that have the potential to stimulate feelings of nostalgia, they serve as key sites and moments for individuals to engage in 'sense making', 'self-exploration', 'self-discovery' and 'yearning for a past' through interactive sociality. Taheri, Gannon and Olya draw attention to the 'transformative' and 'nostalgic' nature of festivals and events as 'part of the varied embodied semiotics produced when dealing with "the past", (Campbell, Smith and Wetherell 2017: 609).

The promotion of local and regional 'heritage' as a resource especially for tourism has been linked to the rise of neo-liberalism, which sees local culture and identity as assets if they can be harnessed to provide foundations for social and economic growth in the face of a decline in manufacturing (Kockel 2007). With sustainability of the resource base seen as a growing issue, the utilisation of heritage is supposed to boost rather than deplete the cultural resource base. This, however, provokes questions concerning the character of heritage as a 'product' and its relation to 'tradition' as a creative process, pointing to the individual as a cultural actor and to issues of authenticity and identity. 'How can an individual, or even a small group, pretend to express collective feelings?', asks Fabiani (2005: 54), putting his finger on a key issue of sociocultural agency. While expressed as a challenge to a purely aesthetic representation of the world, his question points directly to the dark heart of populism as much as to struggles for reconciliation through revisioning of heritages and identities (for examples of the latter, see Pfeiffer and Weiglhofer; also Kockel, this volume).

\subsection{Identity}

The link between heritage and identity has become a commonplace topic (Smith 2006). In anthropological literature, explorations of festivals and identities in general tend to mirror the Durkheimian concern with 'the relationship between festivals and social cohesion (social cohesion being rephrased as collective identity)' (Leal 2016: 586). Festivals, in this analysis, are events engendering what Durkheim would have called 'collective effervescence', which generates a unified group identity based on social organisation and relationships. However, the specific festival form of the Carnival tends to be 
analysed as 'disruptive - or anti-structural ... - events that challenge hegemonic social categories’ (Leal 2016: 586).

Developing an interdisciplinary approach, the authors in this volume share an anthropological understanding of identity as processual (Hall 1999). Most see heritage, with Bortolotto (2007), in similar terms, although its processual character may differ from that of tradition (Kockel 2007). Identity has many facets (Bauman 2001; Triandafyllidou 2014). Kockel (2010: 125f.) has distinguished two types of identity: 'home identities' and 'public identities'. All identities are relational, defined vis-à-vis an 'other', but their orientation may differ. In this model (Figure 1.1), 'home identities' are directed 'inward', defining individuals and groups for themselves, and can be described as 'autological' and 'xenological', depending on whether they are primarily targeting the 'self' or the 'other'. 'Public identities' are directed 'outward', projecting these actors to a wider public, and may be categorised in terms of a 'performance' versus a 'heritage' aspect. Arguably, these distinctions might equally be expressed in terms of 'essentialist' and 'constructivist' identities, but the present distinctions avoid some of the discursive traps associated with those terms.

'Autological' (A) and 'xenological' (X) identification conveys, respectively, insights into one's Self and one's Other(s). 'Performance' (P) identities are expressive, whereas 'heritage' $(\mathrm{H})$ identities are referential. Performing, for example, a commitment to European heritage(s) autologically affirms one's identity for oneself while at the same time referring to a particular heritage

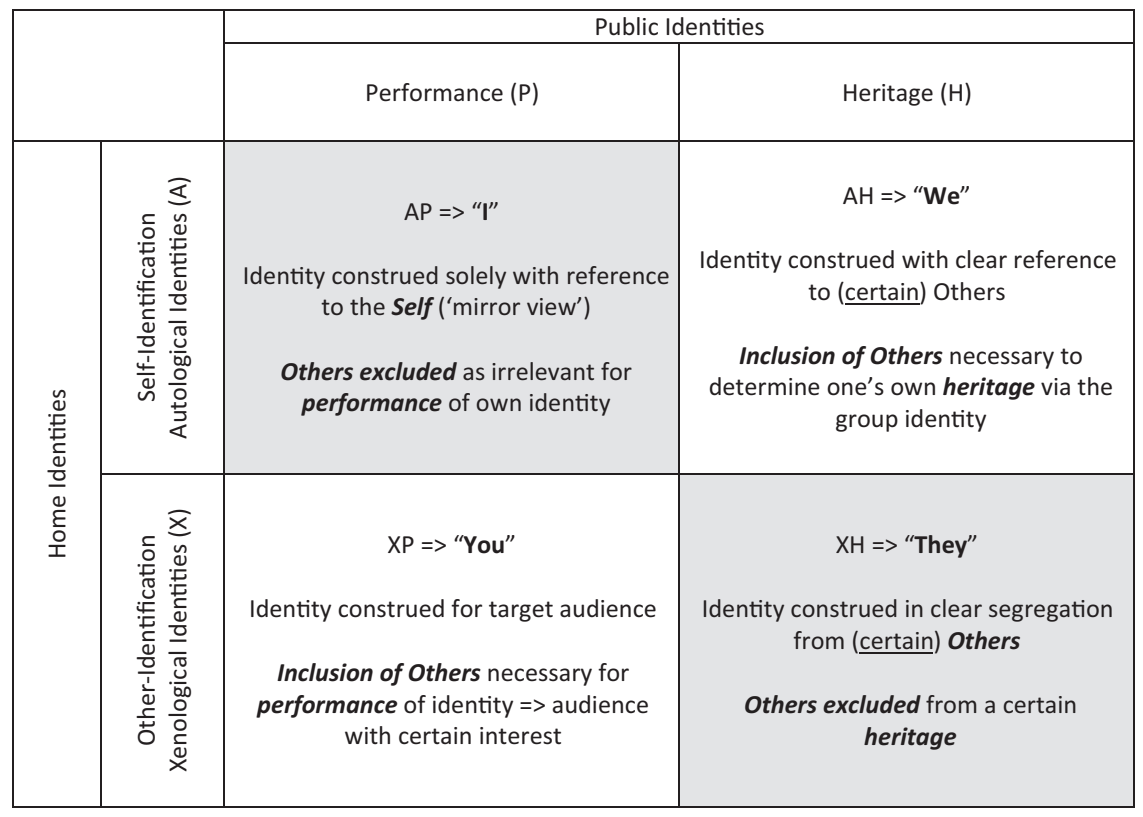

Figure 1.1 Home and public identities (Adapted from Kockel 2010: 126) 
perceived as shared with Others. The same performance xenologically involves an audience who may not share the same heritage(s) but appreciate the significance to the actor(s), while it excludes all those deemed alien to the particular heritage(s) invoked.

In promoting culture and identity in terms of heritage, with a view to furthering inclusion and cohesion, the EU aims at the socioculturally inclusive fields marked AH and XP. Public policy is understandably focussed on 'public' identities. Whether or not identity-related policy and politics works is decided from the 'home' angle, where we often encounter the opposite pattern, AP and $\mathrm{XH}$, with a focus on exclusion, as the Brexit vote in 2016 and the global rise of populism have demonstrated. Yet such an AP-XH constellation need not be confrontational but may merely express neo-liberalism's prevalent spirit of individualism, stressing particularity over similarity and being more concerned with what separates an individual from others.

A note of caution before we proceed: While the concept of 'performance' has been fashionable across humanities and social science disciplines for some time, it needs to be applied with care in a heritage context. The concept implies a certain virtuality that challenges the authenticity of its subject quasi by definition. As Kockel (2010: 126) has highlighted, 'in a performance of Macbeth, we do not see the Scottish king and political reformer, but someone who is pretending to be him, playing out a rather propagandistic horror story'. In considering identity in terms of a performance, are we assigning it a comparable 'as if' quality, marking identity as something we are just play-acting rather than having one? That depends not least on how we think about heritage and tradition as patterns and processes.

The process of creating cultural heritage out of more or less formalised collective ritual practices and 'traditions' has been the object of a certain scholarly curiosity of late. This is due in part to the rather interesting and complex set of sociocultural phenomena and dynamics that are involved, such as top-down and bottom-up policies, construction of meaning, symbolic negotiation and circulation, the emergence of economic and/or political motivation and so on. Testa (this volume) explores the ways certain festivals can be (or aspire to be) considered part of cultural heritage by different social agents or groups in Europe today and tries to explain why such a transformation (or aspiration towards change) is happening. His observations and analysis are based on empirical evidence gathered from ethnographic fieldwork undertaken in Italy, the Czech Republic and Catalonia, augmented by case studies drawn from the literature. The contribution highlights common, indeed panEuropean patterns in the politics of European festive culture and 'immaterial' heritagisation processes, thus advancing some key themes of our research programme, such as how tension between the local and European level pans out in different parts of Europe.

Fournier (this volume) also approaches the performance of different identities in the process of communicating ICH through festivals from the perspective of anthropology, drawing on two examples of festivals appearing on the 
UNESCO representative list of the ICH of humanity. With the 'Processional Giants and Dragons in Belgium and France', he profiles a multinational candidature including several local town festivals. Comparing and contrasting this with a regional festive practice in France, the 'Fest-Noz festive gathering based on the collective practice of international dances of Brittany', Fournier sheds light on the different strategies used to perform and to communicate $\mathrm{ICH}$.

Focussing on the mining heritage of County Durham in England, Pantazatos and Silverman (this volume) interrogate how the Durham Miners' Gala was created and perpetuated, seeking to explain why the Miners' Gala is growing even though the last pit in the area was closed in 1993. They explore the relationship between local mining communities and Durham Cathedral as manifested in the blessing that the mining communities' banners receive during a special service within that building, which is at the core of Durham's World Heritage Site. The success of the Gala is shown to be due to several interacting factors, especially the discursive flexibility of the Gala, whose organisers have been able to generate messages relevant and responsive to particular moments. At the same time, the very iconography of the banners - which form the visual and ideological heart of the Gala - maintain consistency, each one depicting the history, people or legacy of mining, or the deepest identity of the community carrying it. The current success of the Gala is thus entangled with the safe space it provides for epistemic resistance.

Parades are one of the chief means of identity performance, whether as the controversial annual Orange Order parades down the Garvaghy Road in Northern Ireland in the mid-1990s (Kockel 2010) or the rather more subtle ceremonial entry of different banner-bearing groups during the main rally at the annual festival of Sudeten German heritage (Kockel, this volume). Requiring a degree of organisation, they tend to be a feature of institutionalised autological identification, whereas marches and other collective expressions may arise more spontaneously. Autocratic governments, extreme exponents of the AP identity field, tend to use mainly military parades as a regular element of their ritual calendar. In terms of projecting a European identity of any kind, parades are not a common part, although they may feature on occasion, for example, at sporting events or during a European Capital of Culture programme.

\subsection{Europe}

A geopolitical entity whose boundaries and meanings have been subject to protracted debate (see, e.g., Delanty 2017; Kockel, Nic Craith and Frykman 2012; Nic Craith 2006;2008;2009), 'Europe' is used as a shorthand for different entities and thus difficult to define precisely (Kockel, Nic Craith and Frykman 2012: 2):

'Europe' as a sociocultural construct has increasingly come under the magnifying glass and one cannot help the impression that the keener the gaze, the deeper the subject recedes into a haze. Part of the problem with 
the definition of [...] Europe is that its frontiers to the south and east are rather fuzzy. Is Russia part of Europe, or where does Europe's eastern boundary run? Both Turkey and Israel regularly compete in the Eurovision Song Contest, as do various former Soviet Republics whose geographical Europeanness depends rather on where one draws an arbitrary line on the map ... And yet, in much of western and northern Europe, 'Europe' is considered to be somewhere else.

For the purpose of this book, it is not so much 'Europe' as a geographical entity that interests the contributors as the concept of European-ness and whether and how that can be defined. Throughout, we will deal with notions such as 'European landscape', 'European Capitals of Culture', 'European heritage festivals' and 'European languages' - concepts that we use with a certain unease, given our awareness of the 'fuzziness' of such descriptions and the diverse usage across the regions of Europe (see Kockel 1999). What could be Europe's 'imagined communalities' (geglaubte Gemeinsamkeiten; Max Weber); what is the imagined space this generates? The empirical research presented in this book confirms analytical observations (e.g., Delanty 2017; Stock 2017; Chopin 2018) that concepts of Europe differ widely, depending on social as well as geographical location - even when these are not very far apart physically. In the context of Brexit, for example (see Delanty 2017), the concept of 'Europe' triggers different reactions in Scotland compared to England (see Kockel 2015).

Music has long been seen as a key element of European heritage and identity, although that tends to be in the context of 'high culture'. European folk musical expressions, by contrast, are diverse and have been strongly tied to national and regional politics for at least two centuries. Attempts to construct pan-European musical identities, in this context, rely on bringing forward new, original compositions based on these diverse musical identities and often occur in the context of festival commissions. As part of the research programme that gave rise to this book, team members developed and performed a folk oratorio, Rivers of our Being, composed by the Latvian ethnomusicologist Valdis Muktupāvels, drawing on European folk musical traditions. Inspired by 'the rivers of Europe that cross different countries, bringing together diverse cultures across the continent' (CoHERE 2018), the oratorio's official premiere took place on St Andrew's Day, 30 November 2018, symbolising a shared European heritage. It concluded a month-long festival of heritage-related musical and poetic performances, workshops and public lectures. At the time the idea for this kind of European heritage event was initially aired, the organisers could not have foreseen that it would take place in a United Kingdom rocked by that most seismic of European identity performances - the 2016 Brexit vote and its political fallout. The oratorio is at the core of a research-by-practice project, an ongoing endeavour to examine heritage festivals 'from within', which has included the impromptu addition of a coda on the night that referenced Scotland's place in Europe. We will continue to analyse the creative and 
performance process in all its aspects, as well as the aftermath of the oratorio premiere and its festival context.

Drawing on ethnomusicological theories of sound structure and social structure, McKerrell (this volume) examines the ways in which concepts of the 'new' and pan-European belonging surface in a festival folk-orchestra designed, like the oratorio, specifically to express it, while simultaneously drawing upon the sonic affordances of long established, traditional musical heritage from across Europe. His focus is on La Banda Europa, an ensemble formed in 2007/8 specifically to perform complex, new folk-orchestral compositions while drawing on some of the most well-established European folk musical traditions, including the Scottish bagpipes, Swedish nyckelharpa, French hurdy gurdy, Austrian accordion, Galician gaita and Armenian duduk.

Instrumental music as an important element of $\mathrm{ICH}$ is complemented by song, and the oratorio therefore comprised both forms of performing heritage and identity; it also incorporated spoken word recitals of both prose and poetry, highlighting the significance of language in this context. Language - both verbal and pragmatic - is a key element in any performance. Similarly, every speech act is itself a communicative performance. It is therefore important to examine language practices in both official communications and everyday usage and to explore how language(s) is/are used to express, preserve, negotiate and transform identities. Language has the capacity to draw, redraw, extend and transcend boundaries of identity. McFadyen and Nic Craith (this volume) draw attention to these issues by focussing on a contested language, Scots. Drawing parallels with other contested European languages, they examine the significance of linguistic boundaries for identity and a sense of belonging at transnational level. Asking how imaginative and creative forms of performance can accentuate key concepts that are at the core of Europe's cultural heritage, they investigate how heritage practices in a contested language can express uniqueness at a local level, while also promoting social cohesion within a European ideal of 'unity in diversity'.

Building extensively on musical and linguistic heritages as well as on the notion of culture as a resource for economic development, the European Capitals of Culture $(\mathrm{ECoC})$ programme is one of the most expansive initiatives to develop a sense of shared European space, heritage and identity. Clopot and Strani (this volume) reflect on Europeanisation and the attempts to expand and mobilise the concept of a European shared heritage through this programme, focussing on recent and upcoming designations - Valletta (Malta, 2018), Plovdiv (Bulgaria, 2019) and Galway (Ireland, 2020). For more than three decades this programme, described by some researchers (e.g., Immler and Sakkers 2014) as large-scale bottom-up cultural programming, has made cities across Europe compete for the accolade of ECoC. Given this history, the topic has attracted significant research effort, with themes such as identity-building through ECoC (Sassatelli 2002), its empowering agency for regeneration (Meekes, Buda and De Roo 2017), and the reframing of heritage narratives (Hudson et al. 2017; Lähdesmäki 2014). With new guidelines in place for the period past 2019, the 
analysis of the present case study is timely, as it illustrates how one of the main programmes for strengthening European heritage and identity falls short of its mission.

Although the European 'project' has been mythologised to have had a long prehistory, as a vision of peaceful coexistence it was born out of the carnage of two World Wars (see, e.g., Delanty 2017). That this vision appeared until recently to have been achieved may account for some of the apparent contemporary disenchantment with 'Europe' (Kølvraa 2016). In these circumstances, it comes perhaps as no surprise that a 'European spirit' remains most detectable in regions and among groups that have had to grapple with difficult and contested heritages. In this context, Pfeiffer and Weiglhofer (this volume) explore notions of contested places, coping with trauma and long-lasting effects of conflicts. Theatre and storytelling are both means of exploring narratives of self, place and community. Exposing real or fictionalised personal narratives through storytelling and drama has been applied in processes of peace building and reconciliation in contested places because it is an accessible means of dealing with one's own experiences, as well as those of others, in a facilitated space. When stories of life - especially of life within a contested space - are portrayed on a public platform, such as a theatre stage, the meaning of stories is multiplied. Pfeiffer and Weiglhofer explore the use of storytelling and theatre for negotiating reconciliation through two case studies from regions facing historical conflicts of different types. One of these is Northern Ireland, where friction between Protestant and Catholic communities continues today and has increased since the Brexit vote. This is compared and contrasted with frictions in the cross-border region between German Bavaria and Czech Bohemia. The authors reflect on the potential of theatre projects in these regions to not only appease past conflict but also shape identities for the future.

Because Prague was once the capital of the Holy Roman Empire, Bohemia is often described as 'the heart of Europe', not only by the Sudeten Germans. It is one of the three 'heartlands' of Mitteleuropa (Central Europe), a vision invoked in the 1920s and again after the fall of the Iron Curtain (Kockel 1999). The annual festival of Sudeten Germans provides the main case study for Kockel's (this volume) analysis of discourses of displacement and replacement (see Kockel 2012), supplemented by a close look at the multiregional German Youth of the East - since 1974 multinationalised as German Youth in Europe. Kockel considers performances of lost heritage and reconnection with a former homeland, examining how 'vanished homelands' of expellees are performed both in terms of physical spectacle and rhetoric, and in the material and non-material representations of heritage. Placing his investigation in the wider context of post-War reconstruction and European integration, he asks to what extent and how expellee associations have indeed been exponents of a 'European spirit', as they are often nowadays portrayed by their leadership and in their literature, and what, if anything, we might be able to learn from their experience. 


\subsection{Heritage policy for Europe}

How do we translate the findings of research programmes such as ours into policy and/or practice? Strictly speaking, there are no binding legal instruments for culture at a European level, so the answer has to be: by persuasion and example - hence our attempt to create, with the oratorio, a possible vehicle and route for this purpose. Culture falls under the responsibility of each European Union (EU) member state, possibly following the German federal model of Kulturhoheit (cultural sovereignty). Although two other influential supranational institutions, UNESCO and the Council of Europe (CoE), have produced legislation for heritage, these are for the most part 'soft' legal instruments. UNESCO, the leading international standard-setting organisation in the field of cultural heritage, operates through five legally binding Conventions (UNESCO 1954; 1970; 1972; 2001; 2003). However, these conventions also respect national sovereignty. They are signed and ratified at the level of national government, and their terms must be translated into national laws.

The CoE, with its 47 European member states, has issued several conventions regarding cultural heritage, establishing standards for European co-operation and coordination of architectural conservation policies, broadening understanding of cultural heritage to audio-visual heritage and highlighting the social and economic role of ICH (Council of Europe 1985; 1992; 2001; 2005.

The concept of cultural heritage is also at the very heart of the EU constitutional basis, as the Treaty of Lisbon states that the EU shall 'ensure that Europe's cultural heritage is safeguarded and enhanced' (European Union 2007: Article 3.3.).

Although we have described the international conventions above as examples of 'soft' power (Nye 1990), we can nevertheless witness the strong influence of the transnational institutions that issued them on conceptual developments in the cultural heritage field, at both the European and the national levels. Conventions such as those listed above give profile to different aspects of ICH and raise issues of shared knowledge and expertise at a European level, which can generate a substantial body of knowledge, mutual understanding and significant developments in the field of cultural heritage. In the context of this book, there are a number of areas that we would like to draw attention to.

Firstly, many of these conventions raise issues regarding the notion of a 'common European heritage' and the extent to which such an idea can genuinely provide a meaningful framework of shared identity, values and history for people across Europe. European conventions on heritage raise the question of whether a common heritage concept can provide 'enduring points of reference for the present' (Delanty 2017: 2). There is also the issue of whether shared past values are still relevant for, and inclusive of, all European traditions, which include those of minorities we have covered in this book.

As time passes, policy developments with regard to cultural heritage are blurring what were previously regarded as separate and distinct categories. Conceptual links between policies for the preservation of natural heritage and 
the safeguarding of cultural heritage are increasingly debated (Lenzerini and Vrdoljak 2014), as is the distinction between tangible and intangible heritage (Kockel and Nic Craith 2015). The focus in this book is on festivals and other performative activities. While the chapters draw extensively on traditions and intangible cultural heritage, they are all situated in specific places, located in particular built and/or natural environments. For this reason, place-making is a key theme throughout the book.

Heritage festivals provide opportunities to develop this thinking further in that their activities impact far beyond a narrow heritage base. As some chapters in this volume illustrate, heritage festivals, and cultural heritage policies more generally, do not constitute a narrowly defined sector. Increasingly important is their capacity to interact with, and serve, other policy areas. The CoE's 2005 Faro Convention, for example, highlighted the social and economic benefits of preserving cultural heritage as a prerequisite for achieving sustainable development; this is an area of research that deserves considerable further attention. The recent establishment of a Heritage Task Group by Learning for Sustainability Scotland, a United Nations University-recognised Regional Centre of Expertise in this field, is a case in point.

The economic potential of cultural heritage at a transnational level has been recognised by the European Commission (see European Commission 2015; also CHCfE Consortium 2015). In its resolution on new challenges and concepts for the promotion of tourism in Europe, the European Parliament highlighted new opportunities for developing sustainable tourism based on cultural and industrial heritage sites and local traditions (European Parliament 2015). The theme of cultural heritage contributes to the Europe 2020 Strategy for smart, sustainable and inclusive growth. In addition, EU presidencies over the years have highlighted different roles cultural heritage can play, for example, in economic growth or promotion of cultural diversity.

A further trend, also highlighted in our analysis of cultural heritage festivals, involves new developments in the governance of cultural heritage. People and human values are much more central to the concept of cultural heritage than they used to be, and a participatory approach in governance is coming to the fore. In relation to ICH in particular, the UNESCO 2003 Convention for the Safeguarding of the Intangible Cultural Heritage emphasised the central role of communities themselves in safeguarding their heritage. At European level, participatory governance is outlined in the Council of the European Union conclusions on participatory governance of cultural heritage (Council of the European Union 2014). The idea that the user or participant him- or herself can modify the meaning of heritage has indeed come through consistently in our exploration of cultural heritage festivals. Although rooted in traditional knowledge, symbolic meanings are an important feature of $\mathrm{ICH}$ that can be adapted and reshaped according to the needs of local communities, in accordance with the process of tradition (Kockel 2007). This reshaping can occur through performance or through contemporary cultural or artistic productions. That flexibility of ICH can ensure the continued meaningfulness and validity of cultural 


\section{Ullrich Kockel et al.}

forms and expressions for future generations. Finding ways to encourage it that take due account of issues around authenticity and ownership is a key challenge for heritage policy at the global, European, national and local level.

\section{Acknowledgement}

This publication is a result of the European Union-funded Horizon 2020 research project: CoHERE (Critical Heritages: performing and representing identities in Europe). CoHERE received funding from the European Union's Horizon 2020 research and innovation programme under grant agreement No. 693289

\section{References}

Barth, F. (1969), 'Introduction', in F. Barth (ed.), Ethnic groups and boundaries: the social organisation of culture difference (London: Allen \& Unwin), 9-38.

Bauman, Z. (2001), 'Identity in the globalizing world', Social Anthropology 9(2): 121-129.

Bausinger, H. (1961), Volkskultur in der technischen Welt (Stuttgart: Kohlhammer).

Bort, E. ed. (2012), Borne on the carrying stream: the legacy of Hamish Henderson (Edinburgh: Grace Note).

Bortolotto, C. (2007), 'From objects to processes: UNESCO's “Intangible Cultural Heritage”,, Journal of Museum Ethnography 19: 21-33.

Campbell, G., L. Smith and M. Wetherell (2017), 'Nostalgia and heritage: potentials, mobilisations and effects', International Journal of Heritage Studies 23(7): 609-611.

CHCfE Consortium (2015), Culture heritage counts for Europe. Available at: www.encatc. org/culturalheritagecountsforeurope (accessed 14 October 2018).

Chopin, T. (2018), 'Europe and the identity challenge: who are "we”?', European Issues 466, 19 March 2018. Available at: www.robert-schuman.eu/en/doc/questions-d-europe/qe466-en.pdf (accessed 12 January 2019).

Clopot, C. (2017), 'Ambiguous attachments and industrious nostalgias', Anthropological Journal of European Cultures 26(2): 31-51.

CoHERE (2018), Rivers of our Being. Programme leaflet for the premiere of the CoHERE folk oratorio, 30 November 2018.

Council of Europe (2005), 'Council of Europe framework convention on the value of cultural heritage for society'. Available at: www.coe.int/en/web/conventions/full-list/-/ conventions/treaty/199 (accessed 11 January 2019).

Council of Europe (2001), 'European convention for the protection of the audiovisual heritage'. Available at: www.coe.int/en/web/conventions/full-list/-/conventions/treaty/183 (accessed 11 January 2019).

Council of Europe (1992), 'European convention on the protection of the archaeological heritage (Revised)'. Available at: www.coe.int/en/web/conventions/full-list/-/ conventions/treaty/143 (accessed 11 January 2019).

Council of Europe (1985), 'Convention for the protection of the architectural heritage of Europe'. Available at: www.coe.int/en/web/conventions/full-list/-/conventions/treaty/ 121 (accessed 11 January 2019).

Council of the European Union (2014), 'Council conclusions on participatory governance of cultural heritage (2014/C 463/01)'. Available at https://eur-lex.europa.eu/legal-content/ EN/TXT/?uri=CELEX\%3A52014XG1223\%2801\%29 (accessed 11 January 2019). 
Delanty, G. (2017), The European heritage: a critical re-interpretation (London: Routledge).

European Commission (2015), Getting cultural heritage to work for Europe: report of the Horizon 2020 Expert Group on Cultural Heritage. (Luxembourg: Publications Office of the European Union).

European Parliament (2015), 'European Parliament resolution of 29 October 2015 on new challenges and concepts for the promotion of tourism in Europe (2014/ 2241(INI) )'. Available at: www.europarl.europa.eu/sides/getDoc.do?pubRef=-//EP// TEXT+TA+P8-TA-2015-0391+0+DOC+XML+V0//EN (accessed 11 January 2019).

European Union (2007), 'Treaty of Lisbon amending the Treaty on European Union and the Treaty establishing the European Community, signed at Lisbon, 13 December 2007'. Available at: https://eur-lex.europa.eu/legal-content/EN/TXT/ ?uri $=$ celex\%3A12007L\%2FTXT (accessed 11 January 2019).

Fabiani, J.-L. (2005), 'Should the sociological analysis of art festivals be neo-Durkheimian?', Durkheimian Studies 11: 49-66.

Fligstein, N., A. Polyakova and W. Sandholtz (2012), 'European Integration, Nationalism and European Identity', Journal of Common Market Studies 50(S1): 106-122.

Frost, N. (2016), 'Anthropology and festivals: festival ecologies', Ethnos 81(4): 569-583.

Hafstein, V. (2012), 'Cultural Heritage', in: R. Bendix and G. Hasan-Rokem (eds), A companion to folklore (Malden, MA: Wiley), 500-519.

Hall, S. (1999), 'Whose heritage? Un-settling “The Heritage”, re-imagining the post-nation', Third Text 13(49): 3-13.

Harvey, D. (2001), 'Heritage pasts and heritage presents: temporality, meaning and the scope of heritage studies', International Journal of Heritage Studies 7(4): 319-338.

Holtorf, C. and A. Högberg (2013), 'Heritage Futures and the Future of Heritage', in: S. Bergerbrant and S. (eds), Counterpoint: essays in archaeology and heritage studies in honour of Professor Kristian Kristiansen (Oxford: Archaeopress), 739-746.

Hudson, C., L. Sandberg and U. Schmauch (2017), 'The co-creation (of) culture? The case of Umeå, European Capital of Culture 2014', European Planning Studies 25(9): 1538-1555.

Immler, N. and H. Sakkers (2014), '(Re)Programming Europe: European Capitals of Culture: rethinking the role of culture', Journal of European Studies 44(1): 3-29.

Kaina,V. and I. Karolewski (2009), 'EU governance and European identity', Living Reviews in European Governance 4(2). Available at: http://europeangovernance-livingreviews.org/ Articles/lreg-2009-2 (accessed 27 August 2018).

Kilday, A. ed. (1998), Culture and Economic Development in the Regions of Europe (Llangollen: ECTARC).

Kockel, U. (2015), “'Aye'll be back!”: The quest for Scotland's independence, Anthropology Today 31(1): 1-2.

Kockel, U. (2012), 'Toward an ethnoecology of place and displacement', in: U. Kockel, M. Nic Craith and J. Frykman (eds), A companion to the anthropology of Europe (Oxford: Blackwell), 551-571.

Kockel, U. (2010), Re-Visioning Europe: frontiers, place identities and journeys in debatable lands (Basingstoke: Palgrave).

Kockel, U. (2008), 'Putting the folk in their place: tradition, ecology, and the public role of ethnology', Anthropological Journal of European Cultures 17(1): 5-23.

Kockel, U. (2007), 'Reflexive traditions and heritage production', in: M. Nic Craith and U. Kockel (eds), Cultural heritages as reflexive traditions (Basingstoke: Palgrave), 19-33.

Kockel, U. (2002), Regional culture and economic development. explorations in European ethnology (Aldershot: Ashgate).

Kockel, U. (1999), Borderline cases: the ethnic frontiers of European integration (Liverpool: Liverpool University Press). 
Kockel, U., M. Nic Craith and J. Frykman eds (2012), A companion to the anthropology of Europe (Oxford: Blackwell).

Kølvraa, C. (2016), 'European fantasies: on the EU's political myths and the affective potential of utopian imaginaries for European identity', Journal of Common Market Studies 54(1): 169-184.

Kuutma, K. (1998), 'Festival as communicative performance and celebration of ethnicity', Folklore: Electronic Journal of Folklore 7: 79-86.

Lähdesmäki, T. (2016), 'Politics of tangibility, intangibility, and place in the making of a European cultural heritage in EU heritage policy', International Journal of Heritage Studies 22(10): 766-780.

Lähdesmäki, T. (2014), 'European Capital of Culture designation as an initiator of urban transformation in the post-socialist countries', European Planning Studies 22(3): 481-497.

Lähdesmäki, T. (2011), 'R hetoric of unity and cultural diversity in the making of European cultural identity', International Journal of Cultural Policy 18(1): 59-75.

Leal, J. (2016), 'Festivals, group making, remaking and unmaking', Ethnos 81(4): 584-599.

Lenzerini, F. and A.Vrdoljak eds. (2014), International law for common goods: normative perspectives on human rights, culture and nature (Oxford: Hart).

Logan, W., U. Kockel and M. Nic Craith (2015), 'The new heritage studies: origins and evolution, problems and prospects', in: W. Logan, M. Nic Craith and U. Kockel (eds), A companion to heritage studies (Malden, MA: Wiley), 1-25.

MacAloon, J. (1984), 'Olympic Games and the Theory of Spectacle in Modern Societies', in: J. MacAloon (ed.), Rite, drama, festival, spectacle: rehearsals toward a theory of cultural performance (Philadelphia, PA: ISHI), 241-280.

Meekes, J., D. Buda and G. de Roo (2017), 'Leeuwarden 2018: complexity of leisure-led regional development in a European capital of culture', Tijdschrift voor Economische en Sociale Geografie 108(1): 129-136.

Nic Craith, M. (2012), 'Europe’s (un)common heritage(s)', Traditiones 41(2): 11-28.

Nic Craith, M. (2009), 'Writing Europe: a dialogue of "liminal Europeans"', Social Anthropology 17(2): 198-208.

Nic Craith, M. (2008), 'Intangible cultural heritages: the challenges for Europe', Anthropological Journal of European Cultures 17(1): 54-73.

Nic Craith, M. (2006), Europe and the politics of language: citizens, migrants and outsiders (Basingstoke: Palgrave).

Nic Craith, M. and U. Kockel (2015), '(Re-)building heritage: integrating tangible and intangible', in: W. Logan, M. Nic Craith and U. Kockel (eds), A companion to heritage studies (Malden, MA: Wiley), 426-442.

Nic Craith, M. and U. Kockel (2002), 'Culture and economy: towards an agenda for future research', in: U. Kockel (ed.), Culture and economy: contemporary perspectives (Aldershot: Ashgate), 231-240.

Nic Craith, M., U. Kockel and K. Lloyd (2019), 'The Convention for the Safeguarding of the Intangible Cultural Heritage: absentees, objections and assertions', in: N. Akagawa and L. Smith (eds), Safeguarding Intangible Heritage: practices and politics (London: Routledge), 118-132.

Nye, J. S. (1990), 'Soft power', Foreign Policy 80: 153-171.

Sassatelli, M. (2002), 'Imagined Europe: the shaping of a European cultural identity through EU cultural policy', European Journal of Social Theory 5(4): 435-451.

Smith, L. (2006), Uses of heritage (London: Routledge).

Stock, P. (2017), 'What is Europe? Place, idea, action', in: A. Amin and P. Lewis (eds), European Union and disunion: reflections on European identity (London: British Academy), 23-28. 
Taylor, D. (2016), 'Saving the "Live"? Re-performance and Intangible Cultural Heritage', Études Anglaises 69(2): 149-161.

Testa, A. (2017), "Fertility" and the carnival 1: symbolic effectiveness, emic beliefs, and the re-enchantment of Europe', Folklore 128(1): 16-36.

Triandafyllidou, A. (2014), 'National identity and diversity: towards plural nationalism', in: J. Dobbernack and T. Modood (eds), Tolerance, intolerance and respect: hard to accept? (Basingstoke: Palgrave), 159-185.

UNESCO (2003), 'Convention for the Safeguarding of the Intangible Cultural Heritage 2003'. Available at: http://portal.unesco.org/en/ev.php-URL_ID=17716\&URL_DO= DO_TOPIC\&URL_SECTION=201.html (accessed 11 January 2019).

UNESCO (2001), 'Convention on the protection of the underwater cultural heritage 2001'. Available at: http://portal.unesco.org/en/ev.php-URL_ID=13520\&URL_DO=DO_ TOPIC\&URL_SECTION=201.html (accessed 11 January 2019).

UNESCO (1972), 'Convention concerning the Protection of the world cultural and natural heritage 1972'.Available at: http://portal.unesco.org/en/ev.php-URL_ID=13055\&URL_ DO=DO_TOPIC\&URL_SECTION=201.html (accessed 11 January 2019).

UNESCO (1970), 'Convention on the means of prohibiting and preventing the illicit import, export and transfer of ownership of cultural property 1970'. Available at: http:// portal.unesco.org/en/ev.php-URL_ID=13039\&URL_DO=DO_TOPIC\&URL_ SECTION=201.html (accessed 11 January 2019).

UNESCO (1954), 'Convention for the protection of cultural property in the event of armed conflict with regulations for the execution of the convention 1954'. Available at: http:// portal.unesco.org/en/ev.php-URL_ID=13637\&URL_DO=DO_TOPIC\&URL_ SECTION=201.html (accessed 11 January 2019).

Waterton, E. and S. Watson (2015), 'Heritage as a focus of research: past, present and new directions', in: E. Waterton and S. Watson (eds), The Palgrave handbook of contemporary heritage research (London: Springer), 1-17.

Whitehead, C and G. Bozoğlu (2017), 'Heritage and memory in Europe: a review of key concepts and frameworks', CoHERE Critical Archive. Available at: http://cohere-ca.ncl. ac.uk/\#/grid/319 (accessed 2 October 2018). 